\title{
Possible antimicrobial defense by free sugars on the epidermal surface of aquatic vertebrates
}

\author{
Wilfried Meyer ${ }^{1, *}$, Ulrike Seegers ${ }^{2}$, Anke Schnapper ${ }^{1}$, Henner Neuhaus ${ }^{3}$, \\ Werner Himstedt ${ }^{4}$, Edda Toepfer-Petersen ${ }^{5}$ \\ ${ }^{1}$ Institute of Anatomy, University of Veterinary Medicine Foundation, Bischofsholer Damm 15, 30173 Hannover, Germany
${ }^{2}$ Institute of Pharmacology, Toxicology and Pharmacy, and ${ }^{3}$ Fish Disease Research Unit, Centre of Infectious Diseases,
University of Veterinary Medicine Foundation, Bünteweg 17, 30559 Hannover, Germany
${ }^{4}$ Department of Biology, Technical University of Darmstadt, Schnittspahnstr. 3, 64287 Darmstadt, Germany
Department of Reproductive Biology, University of Veterinary Medicine Foundation, Bünteweg 2, 30559 Hannover, Germany
}

ABSTRACT: Biochemical, lectin histochemical, and densitometrical methods demonstrated contents and spectra of free sugars in the skin of aquatic vertebrates (fishes: cod, marine trout, freshwater trout, perch; amphibians: Koa-Tao-Island caecilian, smooth newt, edible frog, South-African clawed toad; mammals: northern fur seal, common seal, otter, Capybara). Total free sugar contents, particularly sialic acids, were relatively higher in freshwater species (perch, Capybara) than in marine species. In amphibians, the caecilian and the newt showed higher amounts of free sugars than the anurans; strong reactions indicated a specific involvement of $\alpha$-L-fucose in mucus functions. Lectin histochemistry demonstrated positive reactions in the stratum superficiale, the outer stratum spinosum, and specific cells of the fish epidermis. The integumental free sugar spectrum of the amphibians was narrow, with generally lower reaction intensities, except for mucus glands. In the mammals, the epidermal cells exhibited rather weak lectin histochemical staining, except for the northern fur seal and the Capybara, where the upper vital epidermis and corneal cells reacted strongly. The mammalian apocrine skin glands, particularly, exhibited positive reaction staining in their secretory endpiece. The free sugar spectrum was similar in all species: $\alpha$-D-mannose, $\beta$-D-N-acetylglucosamine, $\alpha$-D-N-acetylgalactosamine, $\alpha$-D-galactose, $\beta$-D-galactose, $\alpha$-L-fucose, sialic acids (mainly in fish epidermis and skin glands). High concentrations of free sugars on the skin surface possibly impede attacks of commensal skin micro-inhabitants (bacteria, fungi) against the integrity of the epidermis. This features a basic or general biological mechanism that operates before the specific immune system is activated.

KEY WORDS: Free sugars · Aquatic vertebrates · Skin defense

\section{Introduction}

In marine or freshwater biotopes, the integument has to cope with a multitude of microorganisms. The commensal microbial skin-surface flora of aquatic, compared to terrestrial, vertebrates exhibits a similar basic genus and species spectrum (e.g. bacteria: Pseudomonas spp., Acinetobacter spp., Aerosoma spp., Micrococcus spp., Staphylococcus spp., Vibrio spp., or fungi: Saprolegnia spp., Trichophyton spp., Malazessia spp.,
Candida spp.), although this spectrum is continuously influenced by environmental changes (Kloos et al. 1976, Horsley 1977, Krogh \& Christensen 1977, Cahill 1990, Willoughby 1994, Kumamoto \& Vukich 1998, Meyer et al. 2001 [with review for terrestrial mammals], Tlaskalová-Hogenová et al. 2004). In denselyhaired aquatic mammals, like most pinnipeds or otters, a certain mixture of skin-derived organic substances (corneocytes, glandular secretions, etc.) exists on the epidermal surface that may generally nourish the 
microorganisms present, considering that the dense hair coat supplies a safe cover against the outer medium and possible negative influences. This is in contrast to conditions in sparsely-haired species, like the Capybara, and may influence the intensity and necessity of antimicrobial skin defense. Additionally, several bacterial and fungal infections of the skin reported during the last decades, particularly for aquatic mammals, are often a concomitant feature of parasitic invasions or the result of variations in natural environmental factors caused by anthropogenic impacts (Chabreck et al. 1977, Tanaka et al. 1994, Guillot et al. 1998, Schulman \& Lipscomb 1999, Wilson et al. 1999, Van der Heijden et al. 2005).

Thus, an effective defense strategy against the microbial challenge, and/or proliferation control of the microflora present, is a basic need of all invertebrate and vertebrate groups adapted to aquatic biotopes (for lower invertebrates see reviews in Meyer et al. 2006, Klaus et al. 2007). In fishes and amphibians, first defense is normally performed by mucus produced by epidermal cells or secreted from dermal skin glands. This mucus generally contains antimicrobial substances, such as immunoglobin M (IgM), lactoferrin, trypsin, cationic peptides ( $\beta$-defensins), or lysozyme (for fishes see Peleteiro \& Richards 1988, Braun et al. 1990, Cole et al. 1997, Wirth 1998, Smith et al. 2000, Hellio et al. 2002; for amphibians see Diamond 2001, Lai et al. 2002, Duda et al. 2002, Rollins-Smith et al. 2002). In mammals, such substances are secreted by the cells of the epidermis, the outer epithelial hair root sheath, the sebaceous glands and, particularly, the apocrine tubular skin glands (Meyer et al. 2003, Meyer \& Seegers 2004, Meyer 2007). Studies on pinniped skin have indicated, however, that mucus-analogous antimicrobial functions can be additionally exerted on the skin surface by free sugars that are derivatives of glycoconjugates found in the secretions of the apocrine skin glands. This has been demonstrated in a preliminary report for pinnipeds (Meyer et al. 2000), and in more detail for terrestrial mammals, whereby in the latter case it has been shown that epidermal cells also supply substrates for free sugar liberation (Meyer et al. 2001).

The present study focuses on free sugars and their possibly important role in the skin biology of different vertebrate species living more or less permanently in marine or freshwater biotopes. Thus, another means of basic and extracorporal skin defense is highlighted, independent of the special integumental subsystem or tertiary immune organ developed by vertebrates, whereby the keratinocytes, as well as other compartments of the integument, such as all parts of the hair follicle complex, may be major sources of innate immunity-related humoral compounds.

\section{MATERIALS AND METHODS}

Species, sampling, and histological technique. Different species of the main aquatic vertebrate groups were selected for this study-fishes: cod Gadus morhua, sea trout (freshwater trout long-time adapted to the marine environment) Salmo trutta trutta, brown trout Salmo trutta fario, perch Perca fluviatilis; amphibians: Koa Tao Island caecilian Ichthyophis kohtaoensis, smooth newt Triturus vulgaris, edible frog Rana esculenta, African clawed frog Xenopus laevis; mammals: northern fur seal Callorhinus ursinus, common seal Phoca vitulina, otter Lutra lutra, Capybara Hydrochoerus hydrochaeris.

Skin specimens were obtained from the dorsum, flank and abdomen of the sampled individuals. One part of the skin samples was fixed in $10 \%$ formalin containing $2 \%$ calcium acetate, and another part was fixed in Bouin's fluid. Both were maintained for $48 \mathrm{~h}$ at either $4^{\circ} \mathrm{C}$ or room temperature. The material was then dehydrated in a graded series of ethanol, and one part of both fixation sample groups was embedded via xylene in paraffin wax (Paraplast plus, Tyco Health Care); $8 \mu \mathrm{m}$ paraffin sections were deparaffinized in Histoclear (Shandon) and hydrated through descending concentrations of ethanol. One lot of sections was stained with haematoxylin and eosin (HE) for general histology and another lot was processed according to the carbohydrate histochemical approach, including combined control procedures. In general, paraffin tissue processing as described above is thought to be appropriate for the analysis of lectin binding to tissue sections (Rittman \& Mackenzie 1983, Allison 1987, Alroy et al. 1988).

Lectin histochemistry. For the demonstration of terminal sugars, biotinylated lectins were applied in concentrations of 10 to $20 \mathrm{\mu g} \mathrm{ml}^{-1}$ in $0.1 \mathrm{M}$ phosphatebuffered saline (PBS) ( $\mathrm{pH} 7.2$ ) for $30 \mathrm{~min}$ at $20^{\circ} \mathrm{C}$ or $2 \mathrm{~h}$ at $4^{\circ} \mathrm{C}$. The lectins used were: concanavalin A (Con-A), wheat germ agglutinin (WGA), Griffonia simplicifolia agglutinin-I and -II (GSA-I and -II), Dolichos biflorus agglutinin (DBA), soy bean agglutinin (SBA), Bauhinia purpurea agglutinin (BPA), peanut agglutinin (PNA), Ulex europeaeus agglutinin-I (UEA-I), Limax flavus agglutinin (LFA) (all from E.Y. Labs./Medac and Sigma; for lectin specificity see Yamada \& Shimizu 1977, Pearse 1985, Alroy et al. 1988, Spicer \& Schulte 1992, Danguy et al. 1998). The reactions were visualized by peroxidase (PO) conjugated streptavidin, using the 3,3'diaminobenzidine (DAB)-based BioGenex Super Sensitive Universal Immunostaining Kit (BioGenex Laboratories). In this combination, the system is up to $25 \times$ more sensitive than the traditional biotinstreptavidin methods, with better preservation of tissue reactivity and integrity. 
Lectin controls were performed by: (1) addition of saccharides at a final concentration of $0.01 \mathrm{M}$ to the respective lectin solutions (Table 1); (2) substitution of unconjugated lectins for lectin-conjugates; and (3) exposure of sections to $\mathrm{PO}$ and DAB systems without lectins. To detect endogenous peroxidase activity in tissue, certain control sections were reacted with DAB only. In addition, control sections were pre-incubated in $0.3 \%$ hydrogen peroxide in methanol for $30 \mathrm{~min}$ to block intrinsic peroxidase activity.

Densitometrical analysis. For microdensitometrical (cytophotometrical) evaluation of the lectin staining reactions, 3 sections from 4 different slides were used, and the extinction of the cytoplasm of cells of the stratum basale and the stratum granulosum was read with the maximum wavelength for DAB of $465 \mathrm{~nm}$ (Litwin 1979). The measurements were performed using a computer-assisted Zeiss microscope photometer (SMP 03), with a grading monochromator and stabilized light source. The spot size was $1.58 \mu \mathrm{m}$ and the luminous field step $3.1 \mu \mathrm{m}$ in diameter at object level. A total of 40 to 60 cells for each lectin and epidermal layer were measured, and the results were obtained as mean values \pm SE. The results for each lectin and epidermal cell type were evaluated for statistically significant differences between each using ANOVA in a split plot design combined with a $t$-test for paired data.

Biochemical mucus analysis. Carbohydrate biochemical quantitative analysis of fish and amphibian (Xenopus laevis) skin mucus was performed according to Anumula \& Taylor (1991) and Dostálová et al. (1995). The mucus was obtained from freshly dead animals by rinsing with $1 \mathrm{mM} \mathrm{Ca}(\mathrm{OH})_{2}$ (Sawyer 1959). This method strongly stimulates secretion discharge of mucus-producing epidermal cells, particularly in fishes, and also of dermal mucus glands in amphibians; additionally, the mucus obtained is more soluble in this alkaline medium. This method ensures the mucus is pure, and avoids contamination from cellular material, such as epidermal cells, that occurs when mucus is obtained by scraping of the skin surface-the latter has been, unfortunately, a routine technique in studies of fish mucus for many years (see review in Wirth 1998). For a control of successful mucus extraction without tissue impairment in our methodological approach, HE-stained histological sections of the rinsed material were analyzed using light microscopy.

\section{RESULTS}

The biochemical and densitometrical measurements of free sugar contents, or the spectra of free sugars in the mucus produced by fish epidermal cells, amphibian dermal mucus glands (only Xenopus laevis was analysed), and mammalian epidermal cells, apocrine tubular glands and sebaceous glands, demonstrated for fishes and mammals that total free sugar contents were relatively higher in freshwater than in marine species. This was especially true of Perca fluviatilis and Hydrochoerus hydrochaeris, and was corroborated for these species by the densitometrical results of the epidermis, which emphasized the specific role of sialic acids (NeuNAc) in this connection (Figs. 1 \& 2). In amphibians, Ichthyophis kohtaoensis and Triturus vulgaris showed higher amounts of free sugars than the

Table 1. Lectins used in this study and their inhibitory sugars. PO: peroxidase; DAB: 3, 3'diaminobenzidine

\begin{tabular}{|c|c|c|c|}
\hline \multirow{2}{*}{ Abbreviation } & \multirow{2}{*}{$\begin{array}{l}\text { Lectin } \\
\text { Full name }\end{array}$} & \multicolumn{2}{|c|}{ Inhibitory sugar } \\
\hline & & Abbreviation & Full name \\
\hline PO-Con A-DAB & Concanavalin A & $\begin{array}{l}\alpha-D-M a n ; \\
\alpha-D-G l u\end{array}$ & $\begin{array}{l}\alpha \text {-D-mannose } \\
\alpha \text {-D-glucose }\end{array}$ \\
\hline PO-WGA-DAB & Wheat germ agglutinin & $\begin{array}{l}\beta \text {-D-GluNAc> } \\
\text { NeuNAc }\end{array}$ & $\begin{array}{l}\beta \text {-D-N-acetylglucosamine; } \\
\mathrm{N} \text {-acetylneuraminic acid }\end{array}$ \\
\hline PO-GSA-II-DAB & Griffonia simplicifolia agglutinin-II & $\alpha-/ \beta$-D-GluNAc & $\alpha$-/ $\beta$-D-N-acetylglucosamine \\
\hline PO-DBA-DAB & Dolichos biflorus agglutinin & $\alpha$-D-GalNAc & $\alpha$-D-N-acetylgalactosamine \\
\hline PO-SBA-DAB & Soy bean agglutinin & $\begin{array}{l}\alpha-D-G a l N A c> \\
\alpha-D-G a l\end{array}$ & $\begin{array}{l}\alpha \text {-D-N-acetylgalactosamine; } \\
\alpha \text {-D-galactose }\end{array}$ \\
\hline PO-GSA-I-DAB & Griffonia simplicifolia agglutinin-I & $\begin{array}{l}\alpha \text {-D-Gal; } \\
\alpha \text {-D-GalNAc }\end{array}$ & $\begin{array}{l}\alpha \text {-D-galactose; } \\
\alpha \text {-D-N-acetylgalactosamine }\end{array}$ \\
\hline PO-BPA-DAB & Bauhinia purpurea agglutinin & $\begin{array}{l}\beta \text {-D-Gal } \\
\beta \text {-D-GalNAc }\end{array}$ & $\begin{array}{l}\beta \text {-D-galactose; } \\
\beta \text {-D-N-acetylgalactosamine }\end{array}$ \\
\hline PO-PNA-DAB & Peanut agglutinin & $\begin{array}{l}\beta \text {-D-Gal; } \\
\beta \text {-D-GalNAc }\end{array}$ & $\begin{array}{l}\beta \text {-D-galactose } ; \\
\beta \text {-D-N-acetylgalactosamine }\end{array}$ \\
\hline PO-UEA-I-DAB & Ulex europaeus agglutinin-I & $\alpha$-L-Fuc & $\alpha$-L-fucose \\
\hline PO-LFA-DAB & Limax flavus agglutinin & $\begin{array}{l}\text { NeuNAc= } \\
\text { NeuNGc }\end{array}$ & $\begin{array}{l}\text { N-acetylneuraminic acid } \\
\text { N-glycolylneuraminic acid }\end{array}$ \\
\hline
\end{tabular}



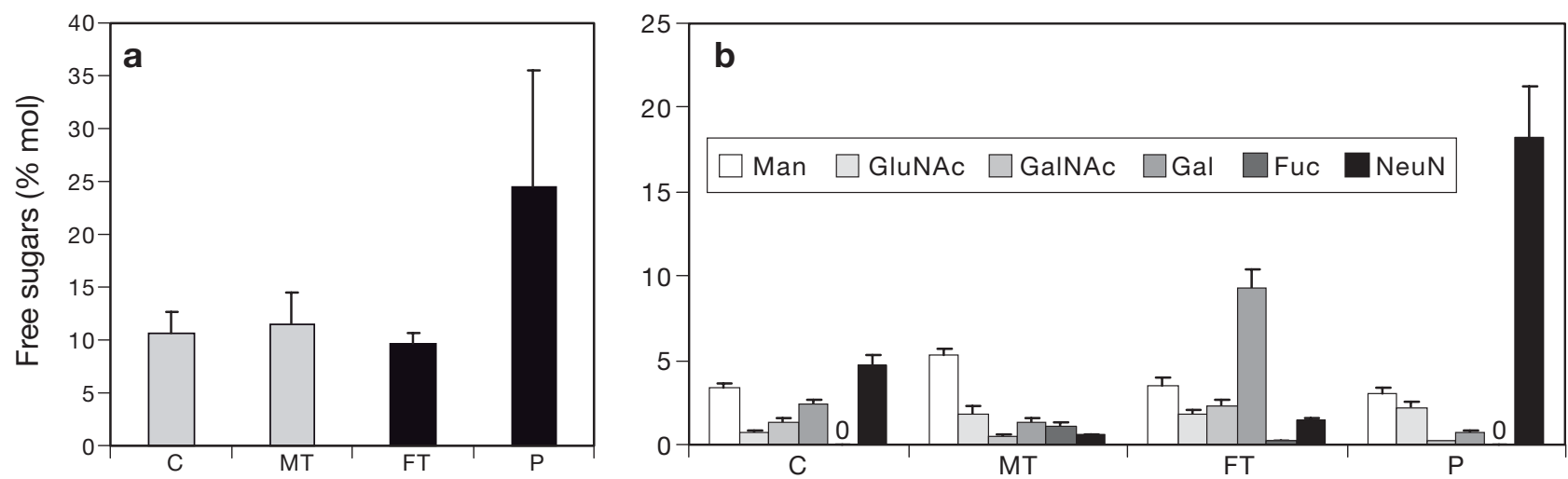

Fig. 1. Comparative amounts of (a) total free sugars and (b) spectrum of free sugars in the epidermal mucus of 4 fish species: marine: $\mathrm{C}=\mathrm{Cod}$ Gadus morhua, MT = Marine trout Salmo trutta trutta; freshwater: FT = Freshwater trout Salmo trutta fario, $\mathrm{P}=$ Perch Perca fluviatilis); shown according to biochemical evaluation, significant differences $(\mathrm{p}<0.01)$ were obtained for Perch as compared to the other 3 fish species; vertical bars are SE. Free sugar definitions in Table 1
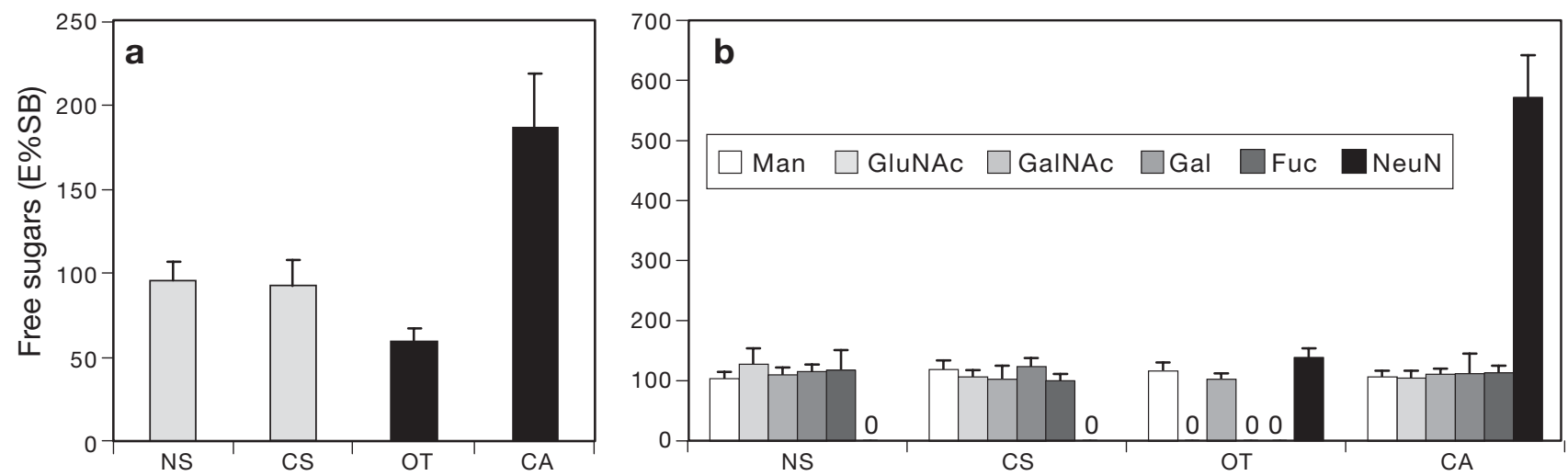

Fig. 2. Comparative amounts of (a) total free sugars and (b) spectrum of free sugars in the upper epidermis (stratum granulosum and barrier region) of the studied mammalian species: marine: NS = northern fur seal Callorhinus ursinus, CS $=$ common seal Phoca vitulina; freshwater: OT = Otter Lutra lutra, CA = Capybara Hydrochoerus hydrochaeris; shown according to densitometrical evaluation ( $\mathrm{E}=$ extinction in percentage [\%] of the values measured in the cells of the stratum basale [SB]), significant differences $(p<0.01)$ were obtained for the Capybara as compared to the other 3 mammalian species studied; vertical bars are SE. Free sugar definitions in Table 1

anuran species. In the amphibians, however, both methodological approaches indicated a specific involvement of $\alpha$-L-fucose $(\alpha$-L-Fuc) in mucus functions (Xenopus laevis, Triturus vulgaris) (Figs. $3 \& 4$ ).

With the help of the glycoconjugate histochemical method, we were able to visualize a spectrum of free sugars corresponding to that obtained by the biochemical analysis, deriving from epidermal cells and different types of glands in the dermis of all the studied species (see Appendix Tables A1 to A4. Available in $A B$ Suppementary Material at www.int-res.com/ articles/suppl/b001p167_app.pdf). Distinctly positive reactions were obtained in cells of the stratum superficiale and of the outer stratum spinosum, but likewise in the goblet, granular, and sacciform cells of the epidermis of the marine and freshwater teleost species (Table A1, Fig. 5a,b). In contrast to the biochemical and densitometrical results, histochemical reaction staining in the freshwater fishes was not more intense when compared to the marine fishes. In the amphibians, the spectrum of free sugars demonstrable by lectin histochemistry in the epidermal cells was clearly not as broad as in the fishes, with generally lower reaction intensities, although it was completed to some extent by positive reaction staining in the dermal mucus and granular glands (Table A2, Fig. 5c,d). In the 4 mammals living in marine (Callorhinus ursinus, Phoca vitulina), or in freshwater (Lutra lutra, Hydrochoerus hydrochaeris) habitats, the epidermal cells exhibited mostly a weak lectin histochemical staining, with the exception of the densely-haired $C$. ursinus and $H$. hydrochaeris, where the outer vital epidermis and the corneal cells sometimes reacted more strongly. Especially in $H$. hydrochaeris, a rather large and sparsely haired rodent with a thick epidermis and only a few apocrine glands, the cells of the stratum granulosum 

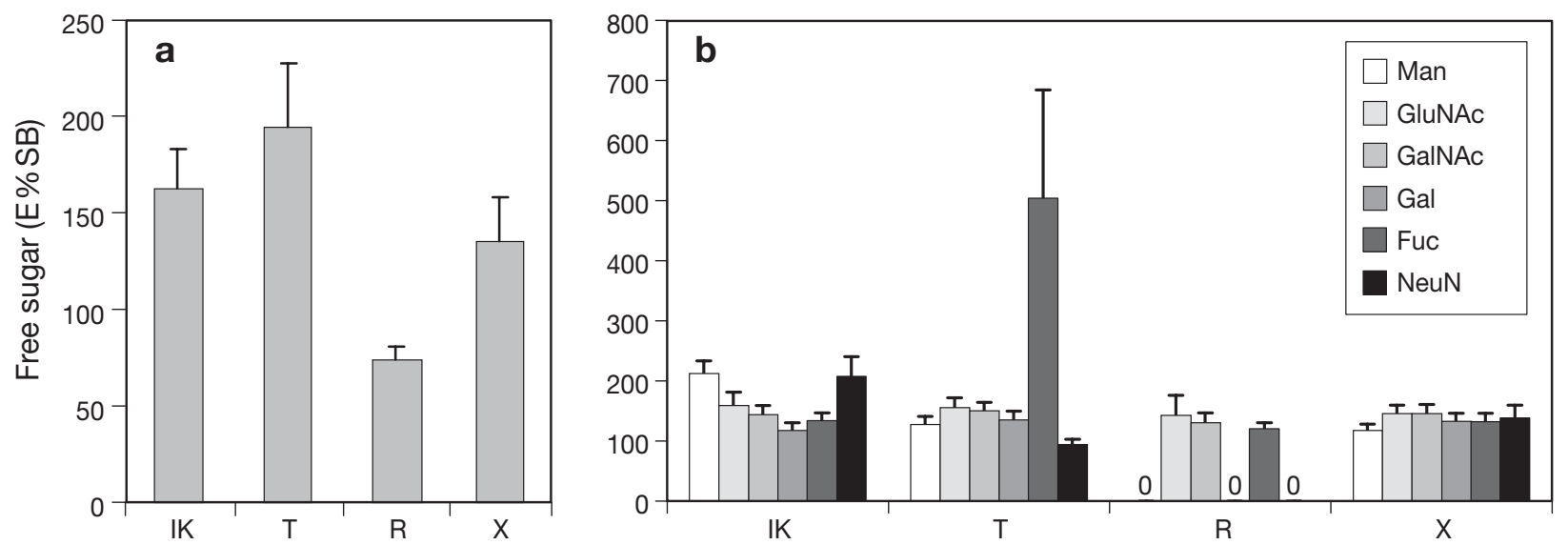

Fig. 3. Comparative amounts of (a) total free sugars and (b) spectrum of free sugar in the upper epidermis (stratum granulosum and barrier region) of the studied amphibian species: IK = Koa Tao Island caecilian Ichthyophis kohtaoensis, $\mathrm{T}=\mathrm{smooth}$ newt Triturus vulgaris, $\mathrm{R}$ = edible frog Rana esculenta, $\mathrm{X}=$ African clawed frog Xenopus laevis; shown according to densitometrical evaluation $(\mathrm{E}=$ extinction in percentage [\%] of the values measured in the cells of the stratum basale [SB]); total free sugars were calculated by addition of the individual sugar values; vertical bars are SE. Free sugar definitions in Table 1

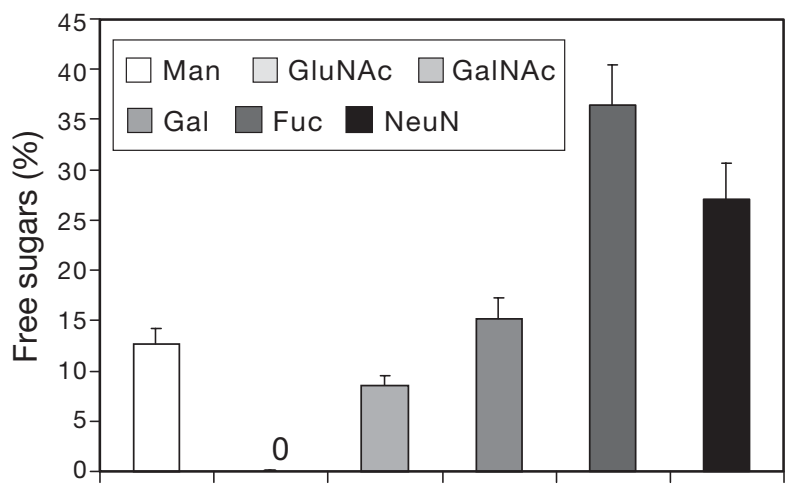

Fig. 4. Xenopus laevis. Spectrum of free sugars in the glandular mucus of the African clawed frog shown according to biochemical evaluation; vertical bars are SE. Free sugar definitions see Table 1

and the upper stratum spinosum reacted distinctly stronger than in the other mammals (Table A3, Fig. $6 \mathrm{~b})$. With regard to the mammalian skin glands, the apocrine tubular glands, particularly, showed clearly positive reaction staining in the secretory cells and the luminal secretion (Table A4, Fig. 6a).

Based on the lectin reactions, the integumental free sugar spectrum in the different vertebrate species studied was composed as follows: (1) fishes: epidermis with $\alpha$-D-mannose (specific lectin: Con A), $\beta$-D-Nacetylglucosamine (WGA, GSA-II), $\alpha$-D-N-acetylgalactosamine (DBA, SBA), $\alpha$-D-galactose (GSA-I), $\beta$-Dgalactose (BPA, PNA), $\alpha$-L-fucose (UEA-I), and sialic acids (LFA); (2) amphibians: epidermis with $\alpha$-Dmannose (Con A), $\beta$-D-N-acetylglucosamine (WGA, GSA-II), $\alpha$-D-galactose (GSA-I), $\beta$-D-galactose (BPA, PNA), and $\alpha$-L-fucose (UEA-I), and dermal glands with $\beta$-D-N-acetylglucosamine (WGA, GSA-II), $\alpha-\mathrm{D}-\mathrm{N}$ - acetylgalactosamine (DBA, SBA), $\alpha$-D-galactose (GSAI), $\beta$-D-galactose (BPA, PNA), and sialic acids (LFA); (3) mammals: epidermis with $\alpha$-D-mannose (Con $A$ ), $\beta$-D-N-acetylglucosamine (WGA), $\alpha$-D-N-acetylgalactosamine (DBA, SBA), $\alpha$-D-galactose (GSA-I), $\beta$-D-galactose (BPA, PNA), and $\alpha$-L-fucose (UEA-I), and apocrine glands with $\alpha$-D-mannose (Con A), $\beta$-D-N-acetylglucosamine (WGA), $\alpha-\mathrm{D}-\mathrm{N}$-acetylgalactosamine (SBA), $\alpha$-D-galactose (GSA-I), $\beta$-D-galactose (BPA, PNA), $\alpha$-L-fucose (UEA-I), and sialic acids (LFA). Generally, the aquatic vertebrate species exhibited rather broad spectra of free sugars in the integument; however, these spectra were somewhat variable in the epidermis of amphibians and mammals. In the latter 2 groups, the skin gland secretions obviously had the most important influence on integumental free sugar contents and spectra.

\section{DISCUSSION}

For pinnipeds and terrestrial mammals, the results of this study generally corroborate those of previous studies, which indicated a protective function of integumental free sugars from different origins (e.g. epidermal cells, dermal glands), and mainly from secretions of the apocrine glands (Meyer et al. 2000, 2001). The free sugar spectra had quite the same qualities independent of varying hair density, as demonstrable when the northern fur seal was compared to the common seal. Only Hydrochoerus hydrochaeris, with its very sparse hair coat, exhibited extraordinarily high amounts of epidermal sialic acids.

Our observations for marine and freshwater fish species are, however, somewhat different from the results 

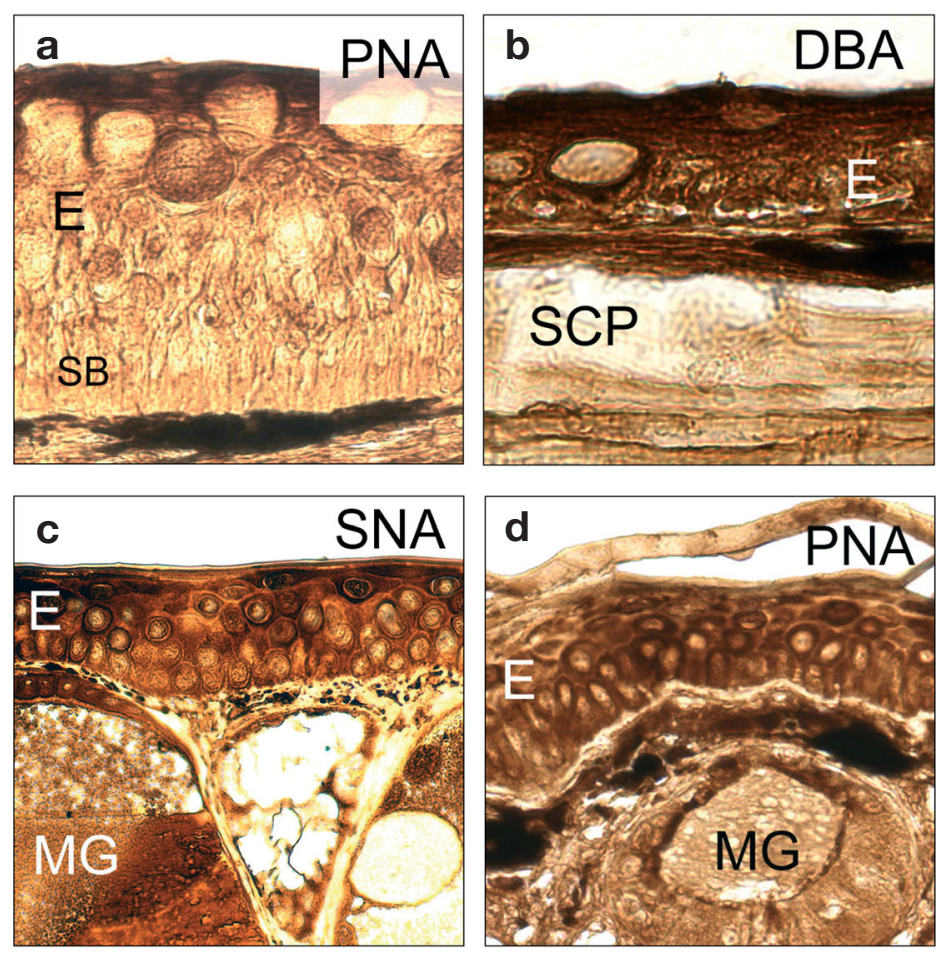

Fig. 5. (a) $\beta$-D-galactose (PNA) in the epidermis of the sea trout Salmo trutta trutta, (shown by the intense staining), especially in the stratum superficiale, including the thin outer mucus layer; (b) $\beta$-N-galactosamine (DBA) in the epidermis of Perca fluvialtilis as a typical freshwater species, strongest reaction intensity also in the stratum superficiale; (c) $\alpha-D-N-$ acetylgalactosamine (SNA) in the epidermal cell layers and in a mucus gland of the dermis (stratum laxum) of Ichthyophis kohtaoensis; (d) $\beta$-Dgalactose (PNA) in the epidermal cell layers and in a mucus gland of the dermis (stratum laxum) of Rana esculenta. $\mathrm{E}=$ epidermis, $\mathrm{MG}=$ mucus gland, $\mathrm{SB}=$ stratum basale, $\mathrm{SCP}=$ scale part. Lectin definitions in Table 1
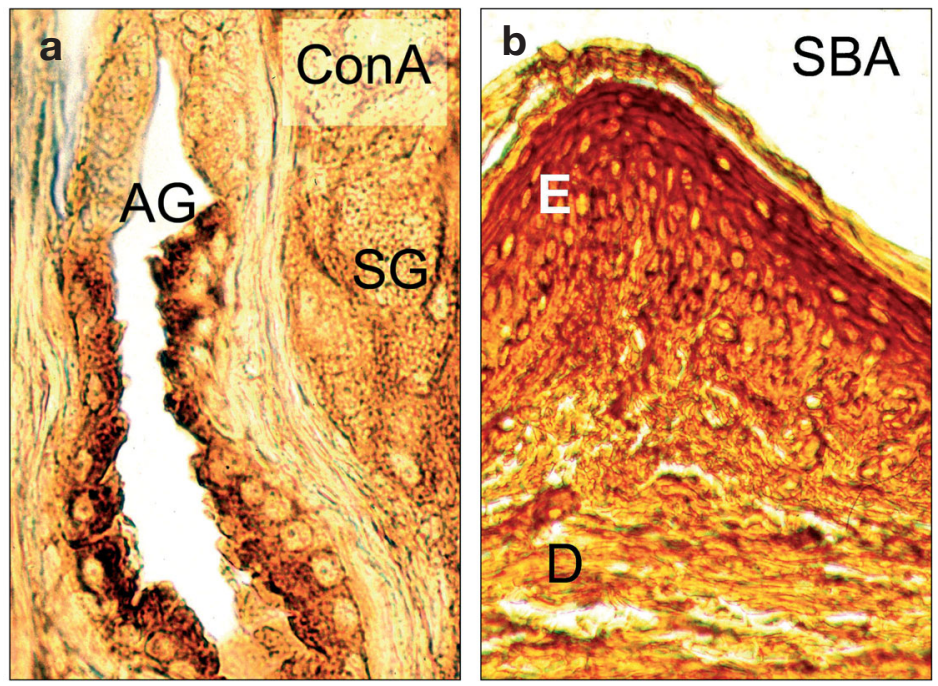

Fig. 6. (a) $\alpha$-D-mannose (Con A) in the strongly reacting secretory epithelium of an apocrine tubular gland of Phoca vitulina (shown by the intense staining); (b) $\beta$-N-galactosamine (SBA) in the upper epidermal layers of Hydrochoerus hydrochaeris. $\mathrm{E}=$ epidermis, $\mathrm{AG}=$ apocrine gland, $\mathrm{D}=$ dermis, $\mathrm{SG}=$ sebaceous gland; for lectin definitions see Table 1 of earlier studies (Kimura et al. 1994, Burkhardt-Holm 1997, Sarasquete et al. 2001, Jung et al. 2002). In contrast to these studies, we did not find great variations in the free sugar spectrum of the epidermal stratum superficiale with the lectin histochemical and densitometrical evaluation methods. This could be due to differences in fixation type and quality, but may also reflect that fish mucus can change in appearance and composition among species and in response to salinity and disease status (Shephard 1994, Roberts \& Powell 2005). The view that mucus qualities adapt to varying living conditions is supported by a comparison of our results of the integumental free sugar contents in extracts of pure epidermal mucus from marine and freshwater species. In the latter, sialic acid contents were remarkably higher. However, freshwater Salmo trutta trutta, longtime adapted to marine conditions, showed rather the same free sugar spectrum and free sugar contents of the mucus or the stratum superficiale of the epidermis, when compared to their original freshwater breeding line. Thus, the broad adaptability of salmonids to both biotopes is highlighted.

The 4 amphibian species exhibited similar spectra of free terminal sugars on and in the skin layers, or in the glandular mucus (Xenopus laevis), as the freshwater fish species; including (besides sialic acid) $\alpha$-L-fucose as another clearly prominent sugar moiety. Comparative biochemical or histochemical studies on the glycoconjugates of the amphibian integument by other authors are rare and mainly concentrate on skin mucus glands, whereby the sugar spectrum found using the lectin histochemical approach only generally corresponds to our results (Els \& Henneby 1990, Schumacher et al. 1994).

All sugars deposited on the skin surface may have been liberated by bacteria and fungi via desintegration of complex glycoconjugates, found as ingredients of skin mucus or as major components of glandular secretions, but also of epidermal cell products, such as from the fucose-rich cells of the stratum corneum disjunctum in Callorhinus ursinus (Ryall 1980, Chin \& Watts 1992, Noble 1993, Meyer et al. $2000,2001)$. Several of these free sugars ( $\alpha$-D-mannose, $N$-acetylglucosamine, $\beta$-D-galactose, $\alpha$-L-fucose), are of specific interest because of their ability to inhibit the adherence/binding of different bacteria to epidermal/epithelial cells (Sharon et al. 1981, Izhar et 
al. 1982, Romero-Steiner et al. 1990, Daunter et al. 1992, McGavin et al. 1993, Morrow et al. 2005). In the same way, 3 of the sugars (N-acetylglucosamine, Nacetylgalactosamine, $\alpha$-L-fucose) prevent the adherence of fungi to the mammalian epidermis (Sobel et al. 1981, Critchley \& Douglas 1987, Ollert et al. 1993).

The freshwater biotope, when compared to the marine milieu, appears to supply better survival, living, and proliferation conditions for microorganisms through relatively high water temperatures and high concentrations of organic material. This is of interest regarding the higher sialic acid accumulations (Perca fluviatilis mucus, Hydrochoerus hydrochaeris epidermis), and equally higher $\alpha$-L-fucose amounts (Triturus vulgaris epidermis, Xenopus laevis mucus) on the skin surface of freshwater vertebrates compared to the marine forms, as demonstrated in this study. The abundance of sialic acids seems of importance in this context, considering that this free sugar type not only regulates mucus viscosity, but also influences and reduces the adherence of different bacterial species, such as Pseudomonas aeruginosa (Wolska et al. 2005, Pastoriza Gallego \& Hulen 2006) to the epidermal cells. Additionally, it controls encapsulation development of bacteria, whereby high amounts of negatively charged sialic acid residues increase anti-adhesive effects (Nelson et al. 2007).

Bacterial adhesion to cells, for example, could be blocked by free sugars binding to lectins of the bacterial outer membrane, e.g. PAII-L (Préville et al. 2006), and in this way protect many of the free sugar residues of the epithelial/epidermal cells from becoming targets for bacterial (or fungal) contact lectins. This idea is of interest considering that oligosaccharide-mediated recognition and adhesion are key points in the early steps of bacterial infection, whereby the carbohydratebinding proteins involved in host recognition and surface adhesion encompass soluble lectins, adhesins and flagellar proteins (Varrot et al. 2006).

In summary, it appears that the high concentrations of free sugars on the skin surface to a considerable extent impede attacks of commensal skin micro-inhabitants (bacteria and fungi) against the integrity of the first important and protecting skin structure, the epidermis. This corroborates the hypothesis that glycans generally participate in innate protection against epithelial/mucosal or glandular pathogens (Morrow et al. 2005, Perrier et al. 2006), and features a basic biological mechanism with low energy requirements that operates before the specific immune system is activated (Meyer et al. 2000, 2001).

Acknowledgements. The excellent technical assistance of Marion Gähle is gratefully acknowledged. For help with skin material, we are greatly indebted to the Fish Breeding Com- pany Elsamer (Carmaret-sur-Mer, France), the Animal Supply Department of the Biological Institute Helgoland (Helgoland, Germany), the late Jochen Hennig (Wisent Zoo, Springe, Germany), the late Gerlinde Müller (Trout Breeding Farm Fredelsloh, Moringen, Germany), the late Dr. Cornelis Jakobus van Nie (Department of Veterinary Anatomy and Biomechanics, Free University Amsterdam, Amsterdam, The Netherlands), the late Prof. Dr. Manfred Röhrs (Institute of Zoology, University of Veterinary Medicine Hannover, Hannover, Germany), Ullrich Seidlitz (Dam Fish Breeding Farm Edersee, Edertal, Germany), and Dr. Michael Stede (Veterinary Investigation Centre for Fish and Fish Products, Cuxhaven, Germany).

\section{LITERATURE CITED}

Allison RT (1987) The effects of various fixatives on subsequent lectin binding to tissue sections. Histochem $\mathrm{J}$ 19:65-74

Alroy J, Ucci AA, Pereira MEA (1988) Lectin histochemistry: an update. In: DeLellis RA (ed) Advances in immunohistochemistry (Neoplasms diagnosis). Raven Press, New York, p 93-131

Anumula KR, Taylor PB (1991) Quantitative determination of phenyl isothiocyanate-derived amino sugars and amino sugar alcohols by high performance liquid chromatography. Anal Biochem 197:113-120

Braun R, Arnesen JA, Rinne A, Hjemeland K (1990) Immunological localization of trypsin in mucus-secreting cell layers of Atlantic salmon, Salmo salar L. J Fish Dis 13: $233-238$

Burkhardt-Holm P (1997) Lectin histochemistry of rainbow trout (Oncorhynchus mykiss) gill and skin. Histochem J 29:893-899

Cahill MM (1990) Bacterial flora of fishes: a review. Microb Ecol 19:21-41

Chabreck RH, Thompson RB, Ensminger AB (1977) Chronic dermatitis in nutria in Louisiana. J Wildl Dis 13:333-334

Chin JC, Watts JE (1992) Relationship between the immune response of sheep and the population dynamics of bacteria isolated from fleecerot lesions. Vet Microbiol 32:63-74

Cole AM, Weis P, Diamond G (1997) Isolation and characterization of pleurocidin, an antimicrobial peptide in the skin secretions of winter flounder. J Biol Chem 272: 12008-12013

Critchley IA, Douglas LJ (1987) Role of glycosides as epithelial cell receptors for Candida albicans. J Gen Microbiol 133:637-643

Danguy A, Decaestecker C, Genten F, Salmon I, Kiss R (1998) Applications of lectins and neoglycoconjugates in histology and pathology. Acta Anat (Basel) 161:206-218

Daunter B, Forbes KL, Sanderson BM, Morrison J, Wright G (1992) Inhibition of binding of bacteria to amniochorionic membranes by amniotic fluid. Eur J Obstet Gynecol Reprod Biol 47:95-102

Diamond G (2001) Nature's antibiotics: the potential of antimicrobial peptides as new drugs. Biologist 48:209-212

Dostálová Z, Calvete JJ, Sanz L, Toepfer-Petersen E (1995) Boar spermadhesin AWN-1: oligosaccharide and zona pellucida binding characteristics. Eur J Biochem 230:329-336

Duda TF Jr, Vanhoye D, Nicolas P (2002) Roles of diversifying selection and coordinated evolution in the evolution of amphibian antimicrobial peptides. Mol Biol Evol 19: 858-864

Els WJ, Henneby R (1990) Histological features and histochemistry of the mucous glands in ventral skin of the frog 
(Rana fuscigula). Histol Histopathol 5:343-348

Guillot J, Petit T, Degorce-Rubiales F, Gueho E, Chermette R (1998) Dermatitis caused by Malazessia pachydermatis in a California sea lion (Zalophus californianus). Vet Rec 142: 311-312

Hellio C, Pons AM, Beaupoil C, Bourgougnon N, Gal YL (2002) Antibacterial, antifungal and cytotoxic activities of extracts from fish epidermis and epidermal mucus. Int $\mathrm{J}$ Antimicrob Agents 20:214-219

Horsley RW (1977) A review of the bacterial flora of teleosts and elasmobranchs, including methods of analysis. J Fish Biol 10:529-553

Izhar M, Nuchamowitz Y, Mirelman D (1982) Adherence of Shigella flexneri to guinea pig intestinal cells is mediated by a mucosal adhesion. Infect Immun 35:1110-1118

Jung KS, Ahn MJ, Lee YD, Go GM, Shin TK (2002) Histochemistry of six lectins in the tissues of the flat fish Paralichthys olivaceus. J Vet Sci 3:293-301

Kimura M, Hama Y, Sumi T, Asakawa M and others (1994) Characterization of a deaminated neuraminic acidcontaining glycoprotein from the skin mucus of the loach, Misgurnus anguillicaudatus. J Biol Chem 269: 32138-32143

Klaus JS, Janse I, Heikoop JM, Sanford RA, Fouke BW (2007) Coral microbial communities, zooxanthellae and mucus along gradients of seawater depth and coastal pollution. Environ Microbiol 9:1291-1305

Kloos WE, Zimmerman RJ, Smith RF (1976) Preliminary studies on the characterization and distribution of Staphylococcus and Micrococcus species on animal skin. Appl Environ Microbiol 31:53-59

Krogh HV, Christensen S (1977) Beiträge zur Dermatologie von Hund und Katze. Tierarztl Prax 5:389-393

Kumamoto KS, Vukich DJ (1998) Clinical infections of Vibrio vulnificus: a case report and review of the literature. J Emerg Med 16:61-66

Lai R, Liu H, Hui Lee W, Zhang Y (2002) An anionic antimicrobial peptide from toad Bombina maxima. Biochem Biophys Res Commun 295:796-799

Litwin JA (1979) Histochemistry and cytochemistry of 3,3'diaminobenzidine. A review. Folia Histochem Cytochem $17: 3-28$

McGavin MH, Krajewska-Pietrasik D, Ryden C, Hook M (1993) Identification of a Staphylococcus aureus extracellular matrix-binding protein with broad specificity. Infect Immun 61:2479-2485

Meyer W (2007) Demonstration of lysozyme and antimicrobial peptides in the temporal gland of the African elephant (Loxodonta africana). Mamm Biol 72:251-255, doi: 10.1016/ j.mambio.2006.05.003

Meyer W, Seegers U (2004) A preliminary approach to epidermal antimicrobial defense in the Delphinidae. Mar Biol 144:841-844

Meyer W, Bollhorn M, Stede M (2000) Aspects of general antimicrobial properties of skin secretions in the common seal Phoca vitulina. Dis Aquat Org 41:77-79

Meyer W, Neurand K, Tanyolac A (2001) General antimicrobial properties of the integument in fleece producing sheep and goats. Small Rumin Res 41:181-190

Meyer W, Seegers U, Herrmann J, Schnapper A (2003) Further aspects of the general antimicrobial properties of pinniped skin secretions. Dis Aquat Org 53:177-179

Meyer W, Sidri M, Bruemmer F (2006) Glycohistochemistry of a marine sponge, Chondrilla nucula (Porifera, Desmospongiae), with remarks on a possibly related antimicrobial defense strategy and a note on exopinacoderm function. Mar Biol 150:313-319
Morrow AL, Ruiz-Palacios GM, Jiang X, Newburg DS (2005) Human-milk glycans that inhibit protect breast-feeding infants against infectious diarrhea. J Nutr 135:1304-1307

Nelson AL, Roche AM, Gould JM, Chim K, Ratner AJ, Weiser JN (2007) Capsule enhances pneumococcal colonization by limiting mucus-mediated clearance. Infect Immun 75 : 83-90

Noble WC (ed) (1993) The skin microflora and microbial skin disease. Cambridge University Press, Cambridge

Ollert MW, Söhnchen R, Korting HC, Ollert U, Bräutigam S, Bräutigam W (1993) Mechanisms of adherence of Candida albicans to cultured human epidermal keratinocytes. Infect Immun 61:4560-4568

Pastoriza Gallego M, Hulen C (2006) Influence of sialic acid and bacterial sialidase on differential adhesion of Pseudomonas aeruginosa to epithelial cells. Colloids Surf B Biointerfaces 52:154-156

Pearse AGE (1985) Histochemistry: rheoretical and applied. 4th edn. Vol 2: Analytical technology. Churchill Livingstone, Edinburgh

Peleteiro MC, Richards RH (1988) Immunocytochemical studies on immunoglobulin-containing cells in the epidermis of rainbow trout Salmo gairdeneri Richardson: influences of bath vaccination. J Fish Biol 32:845-858

Perrier C, Sprenger N, Corthésy B (2006) Glycans on secretory component participate in innate protection against mucosal pathogens. Biol Chem 281:14280-14287

Préville C, Marotte K, Moumé-Pymbock M, Sabin C, Imberty A, Roy R (2006) Glycomimetic ligands of the PAII-L from Pseudomonas aeruginosa. XIIIrd Int Carb Symp (Whistler, Canada, July 23-28, 2006), National Research Council of Canada, Ottawa, Abstracts, p 214

Rittman BR, Mackenzie IC (1983) Effects of histological processing on lectin binding patterns in oral mucosa and skin. Histochem J 15:467-474

Roberts SD, Powell MD (2005) The viscosity and glycoprotein biochemistry of salmonid mucus varies with species, salinity and the presence of amoebic gill disease. J Comp Physiol B 175:1-11

Rollins-Smith LA, Reinert LK, Miera V, Conlon JM (2002) Antimicrobial peptide defenses of the Tarahumara frog, Rana tarahumarae. Biochem Biophys Res Commun 297: 361-367

Romero-Steiner S, Witek T, Balish E (1990) Adherence of skin bacteria to human epithelial cells. J Clin Microbiol 28: 27-31

Ryall C (1980) The ecology of athlete`s foot. New Sci 87: 528-530

Sarasquete C, Gisbert E, Ribeiro L, Vieira L, Dinis MT (2001) Glycoconjugates in epidermal, branchial and digestive mucous cells and gastric glands of gilthead sea bream, Sparus aurata, Senegal sole, Solea senegalensis and Siberian sturgeon, Acipenser baeri development. Eur J Histochem 45:267-278

Sawyer PJ (1959) Effects of certain chemicals on mucusproducing cells of Petromyzon marinus. Trans Am Fish Soc 88:305-309

Schulman FY, Lipscomb TP (1999) Dermatitis with invasive ciliated protozoa in dolphins that died during the 19871988 Atlantic bottlenose dolphin morbilliviral epizootic. Vet Pathol 36:171-174

Schumacher U, Adam E, Hauser F, Probst JC, Hoffmann W (1994) Molecular anatomy of a skin gland: histochemical and biochemical investigations on the mucous glands of Xenopus laevis. J Histochem Cytochem 42:37-65

Sharon N, Eshdat Y, Silverblatt FJ, Ofek I (1981) Bacterial adherence to cell surface sugars. Ciba Found Symp 80: 
119-141

Shephard KL (1994) Functions for fish mucus. Rev Fish Biol Fish 4:401-429

Smith VJ, Fernandes JM, Jones SJ, Kemp GD, Tatner MF (2000) Antibacterial proteins in rainbow trout, Oncorhynchus mykiss. Fish Shellfish Immunol 10:243-260

Sobel JD, Myers PG, Kaye D, Levison ME (1981) Adherence of Candida albicans to human vaginal and buccal epithelial cells. J Infect Dis 143:76-82

Spicer SS, Schulte BA (1992) Diversity of cell glycoconjugates shown histochemically: a perspective. J Histochem Cytochem 40:1-38

Tanaka E, Kimura T, Wada S, Hatai K, Sonoda S (1994) Dermatophytosis in a Steller sea lion (Eumetopias jubatus). J Vet Med Sci 56:551-553

Tlaskalová-Hogenová H, Štěûpánková R, Hudcovic T, Tučková $\mathrm{L}$ and others (2004) Commensal bacteria (normal microflora), mucosal immunity and chronic inflammatory and autoimmune diseases. Immunol Lett 93:97-108

Van der Heijden KM, Szabo MP, Egami MI, Pereira MC, Matushima ER (2005) Histopathology of tick-bite lesions in naturally infested capybaras (Hydrochoerus hydrochaeris) in Brazil. Exp Appl Acarol 37:245-255

Editorial responsibility: Howard Browman (Associate Editorin-Chief), Storebø, Norway
Varrot A, Saboia K, Imberty A (2006) Determination of the biochemical and structural properties of adhesins and lectins. XIIIrd Int Carb Symp (Whistler, Canada, July 23-28, 2006), National Research Council of Canada, Ottawa, Abstracts, p 76

Willoughby LG (1994) Fungi and fish diseases. Pisces Press, Stirling

Wilson B, Arnold H, Bearzi G, Fortuna CM and others (1999) Epidermal diseases in bottlenose dolphins: impacts of natural and anthropogenic factors. Proc R Soc Lond B Biol Sci 266:1077-1083

Wirth U (1998) Vergleichende Untersuchungen zur Struktur und Funktion der Hautschichten bei Fischen unter besonderer Berücksichtigung von Hautsekreten. Dr. rer. nat. thesis, University of Hannover

Wolska K, Rudaś P, Jakubczak A (2005) Reduction in the adherence of Pseudomonas aeruginosa to human buccal epithelial cells with neuraminidase inhibition. Pol J Microbiol 54:73-76

Yamada K, Shimizu S (1977) The histochemistry of galactose residues of complex carbohydrates as studied by peroxidase labelled Ricinus communis agglutinin. Histochemistry 53:143-156

Submitted: August 1, 2007; Accepted: November 29, 2007 Proofs received from author(s): December 23, 2007 